\title{
Willingness to pay for management and preservation of natural, semi-urban and urban beaches in Italy
}

\section{Ilaria Rodella $a^{\mathrm{a}, *}$}

rdllri@unife.it

\section{Fabio Madau ${ }^{\mathrm{b}}$}

Massimiliano Mazzanti

Corinne Cor

Donatella Carboni $^{\mathrm{e}}$

Kizzi Utizi ${ }^{\mathrm{d}}$

Umberto Sim

a Department of Engineering, Ferrara University, Via Saragat 1, 44122 Ferrara, Italy

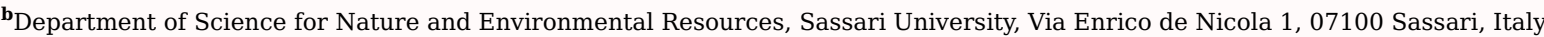

${ }^{\mathbf{c}}$ Department of Economics and Management, Ferrara University, Via Viltapaletto 11, 44121 Ferrara, Italy

dDepartment of Physics and Earth Sciences, Ferrara University, Via Saragat 1, 44122 Ferrara, Italy

${ }^{\mathbf{e}}$ Department of Human and Social Sciences, Sassari University, Via Roma 151, 07100 Sassari, Italy

${ }^{*}$ Corresponding author.

\section{Abstract}

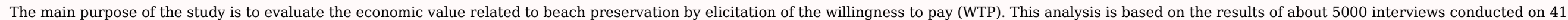

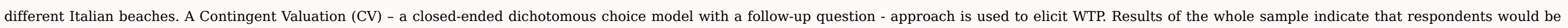

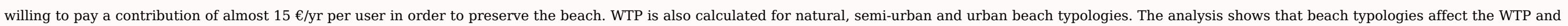
similarities and significant differences of each typology are found according to respondents!- sociometric indicators.

Keywords: Beach types; Users' perception; Willingness to pay; Beach management; Italy

\section{Introduction}

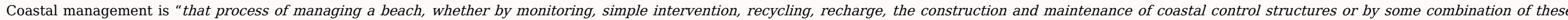

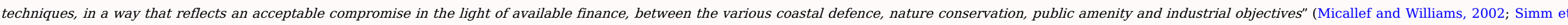

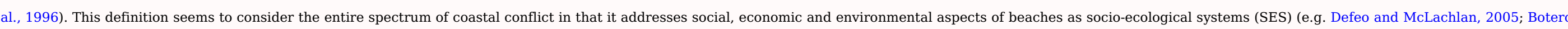

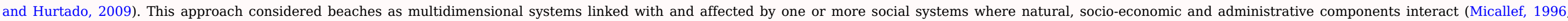

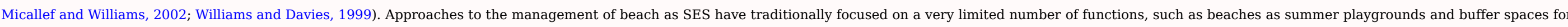

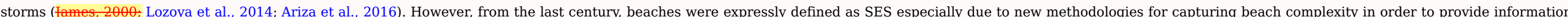




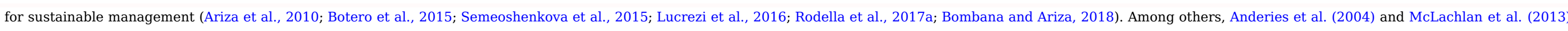

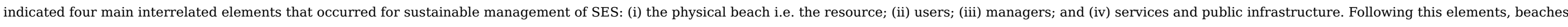

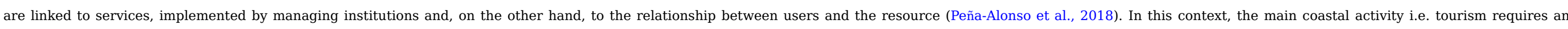
integrated approach of all aforementioned aspects that can be translated into a sustainable coastal tourism development (Mazzanti, 2002b).

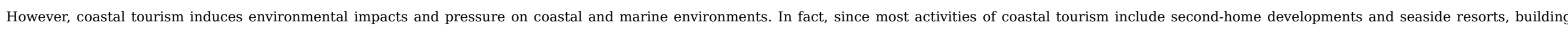

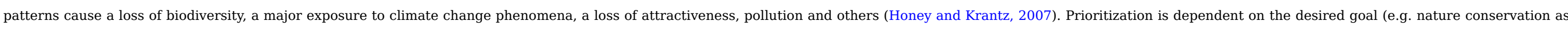

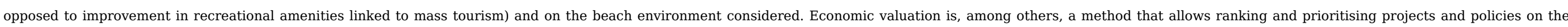
basis of socio-economic and environmental costs and benefits (Ozdemiroglu and Hails, 2016).

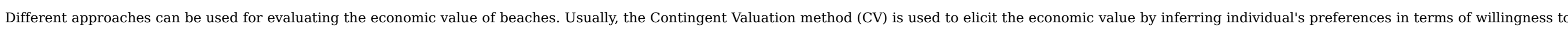

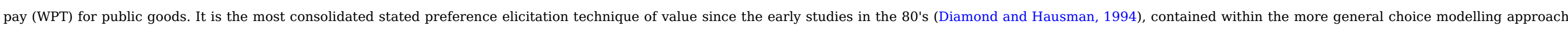

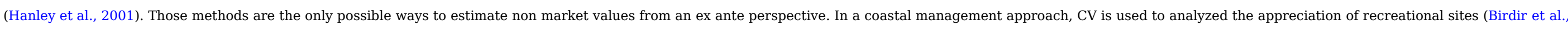

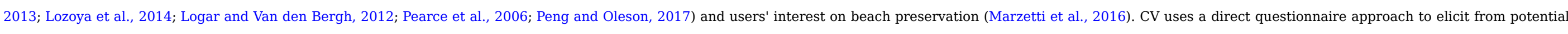

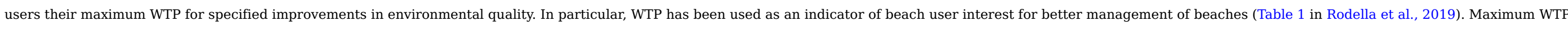

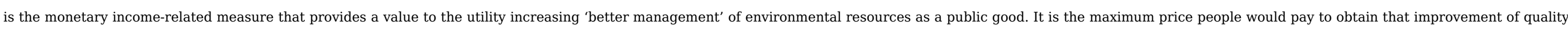

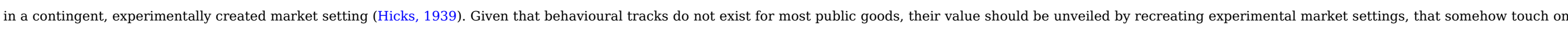
marketing studies, but are applied with welfare economics purposes, namely measuring and weighting social costs and benefits of projects (Atkinson and Mourato, 2015).

Table 1 Types of beaches in the Italian littorals.

\section{alt-text: Table 1}

Beach type

NATURAL BEACHES. Located far from urban and semiurban areas. Accessibility is reduced. Access is possible by private transport, on foot or by boat, but not by
public transport. Such beaches are often preserved Usually no facilities for users.

Environment/Characteristics/recreational Located in marine or terrestrial protected area far from services any population center. They are characterized by rustic seafront, forested-dunes area and/or coconut plantations and low level of interaction between human activities and environment. These beaches correspond to natural free beaches (almost no equipment, facilities or opportunities for commercial activities). These beaches presented only conservational characteristics

Shape Linear, pocket beach

Urbanization levels (Ariza et al., 2008)

They are found outside the main nucleus located close to very low-density urbanized areas (under $30 \%$ of the hinterland being urbanized) in uninhabited areas

Accessibility are close or within walking distance at a distance $>300 \mathrm{~m}$ of any road or by boat.
SEMI-URBAN BEACHES. Entities located in medium or low population density areas. With reduced accessibility and moderate attendance. The degree of artificiality of the coastline is less than at urban beaches. The number of facilities is limited.

Located outside urban areas. These areas may be associated with permanent residence and a small supply of services (primary schools, religious centers, shops or cafes). Thes areas are identified by the simultaneous presence of equipped beaches and natural free beaches (for instance in adjacent stretches of coast that cover the littoral). These beaches presented both recreational and conservational characteristics

\section{Linear, artificial $\quad$ Linear - artificial}

embayed beach, pocket beach

They are found in a residential area outside the main municipality nucleus with a maximum of $50 \%$ urbanized hinterland (low density)

\begin{tabular}{|c|c|}
\hline $\begin{array}{l}\text { There is public } \\
\text { transport } \\
\text { during the day } \\
\text { with a } \\
\text { frequency } \geq 1 \mathrm{~h}\end{array}$ & $\begin{array}{l}\text { Access not adapted for } \\
\text { disabled users in a } \\
\text { considerable part of the } \\
\text { beach ( }>1 / 3 \text { total } \\
\text { tenghtlength). }\end{array}$ \\
\hline
\end{tabular}

URBAN BEACHES. Located in urban areas. With many types of commercial services, accommodation and facilities. Their recreational value is often far from their conservation value.

Located in an urban environment. With wellestablished utilities. Beaches present high or medium level of interaction between human activities and environment. Specialized services such as banks, postal services, and centers for business activity. In these areas, commercial
activities related to the sea can be found. These activities related to the sea can be found. These
beaches presented an high recreational level

Linear, artificial Linear pocket beach embay beach

Located within the main nucleus of a municipality with over $60 \%$ of urbanized hinterland of high density

\section{Accessible by Some}

public transport. equipment such as umbrellas and hammocks, often require a fee.
Access to

eache and facilities is adapted to the needs 


\begin{tabular}{|c|c|c|c|}
\hline Accommodation & $\begin{array}{l}\text { Outlying villages (>500 m). Possible to find isolated } \\
\text { buildings. }\end{array}$ & $\begin{array}{l}\text { The availability } \\
\text { of housing is low } \\
\text { or nonexistent. }\end{array}$ & $\begin{array}{l}\text { There may be a } \\
\text { small supply of } \\
\text { accommodation } \\
\text { in residential } \\
\text { complexes. }\end{array}$ \\
\hline Facilities & No beach equipment. & $\begin{array}{l}\text { Different } \\
\text { services (public } \\
\text { toilets, showers } \\
\text { and footbaths, } \\
\text { parking, access, } \\
\text { regular cleaning } \\
\text {...). }\end{array}$ & $\begin{array}{l}\text { here are } \\
\text { security and } \\
\text { surveillance } \\
\text { services. }\end{array}$ \\
\hline
\end{tabular}

There may be small

tourist villages inhabited

all year round.

The monitoring service is
usually not permanent
throughout the year.
usually not permanent
Accommodation/lodging in residential

complexes.

\begin{tabular}{l|l|l} 
With diverse & There are & The \\
facilities & security and & monitoring \\
(restrooms, & surveillance & service is \\
showers and & services. & usually \\
footbaths, & permanent \\
parking areas, & & throughout \\
good access, & & the year.
\end{tabular}

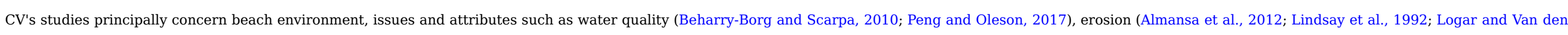

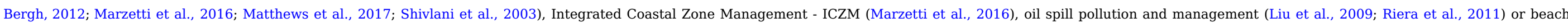

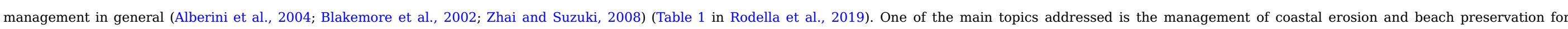

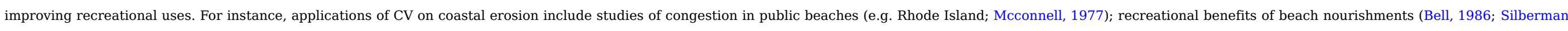

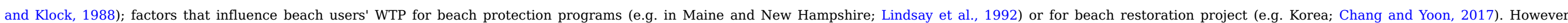

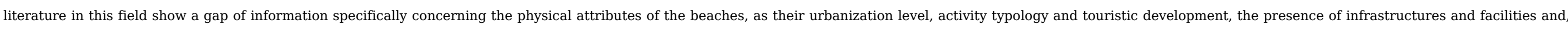

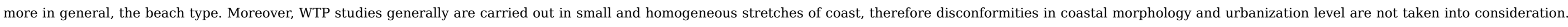

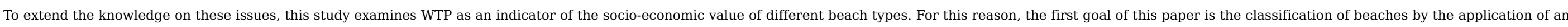

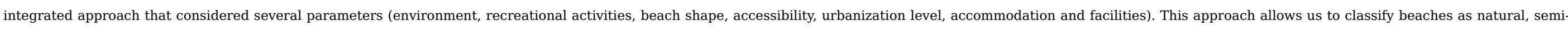

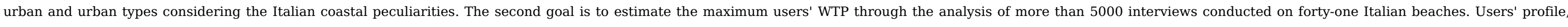

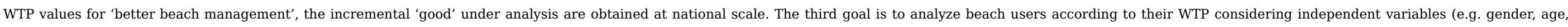

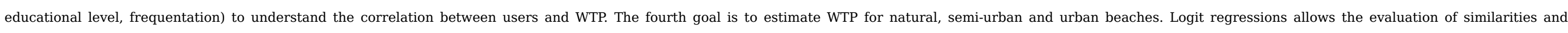

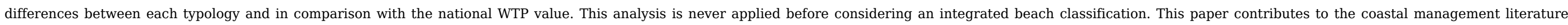
comparing a WTP valuation in different beach types.

\section{Study area}

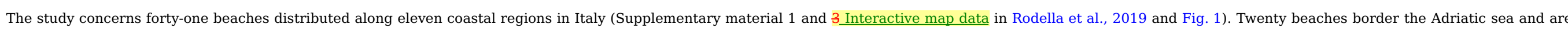

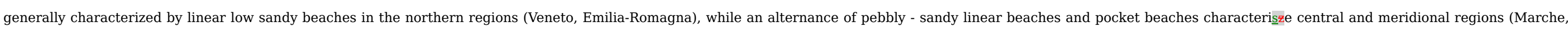

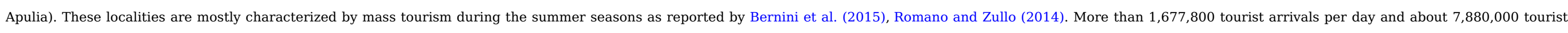
presences per day were registered in Adriatic study sites in 2015 (Supplementary material 1 in Rodella et al., 2019). 

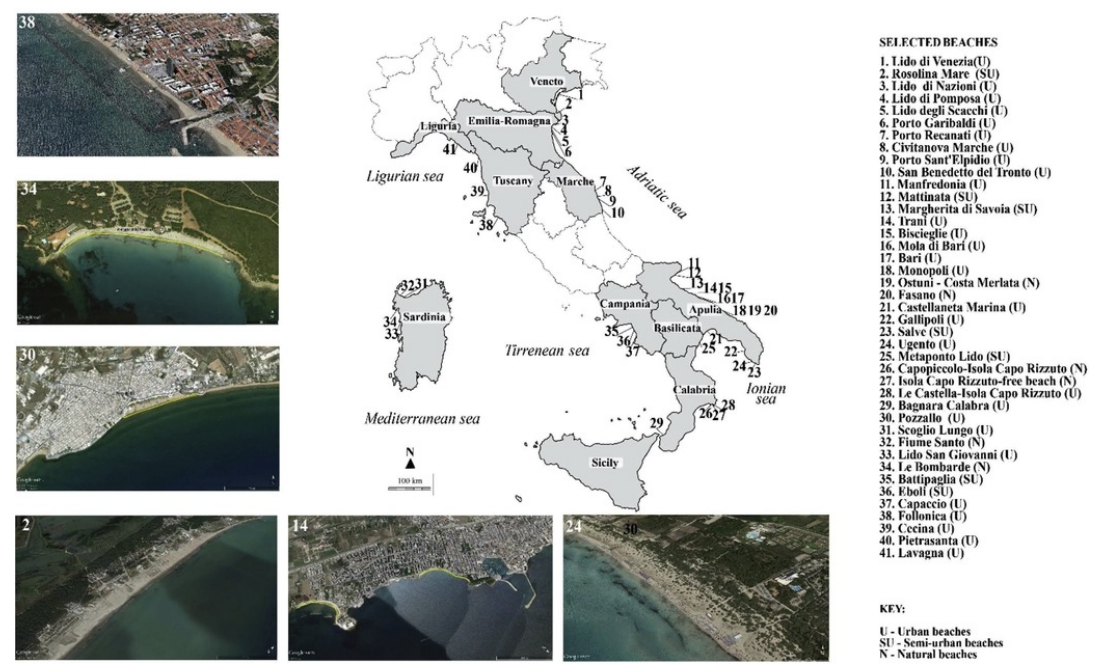

26

Fig. 1 Location map. Photos illustrate (Lecce) (Source: Google Earth photos).

alt-text: Fig. 1

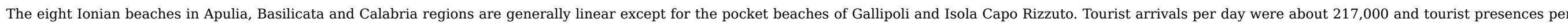
day were more than 1,300,000 in the 2015 year. Tourist information regarding Isola Capo Rizzuto are unknown.

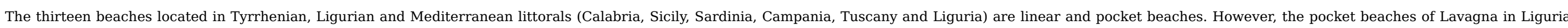
and Scoglio Lungo in Sardinia are artificial. In 2015, the number of tourist arrivals per day in the Mediterranean and Tyrrhenian study sites was 679,494 and the tourist presences per day were 3,030,200.

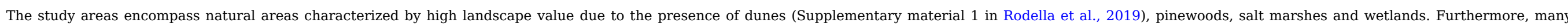

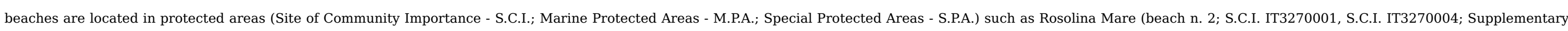

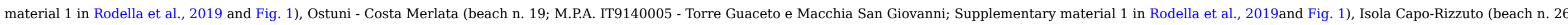

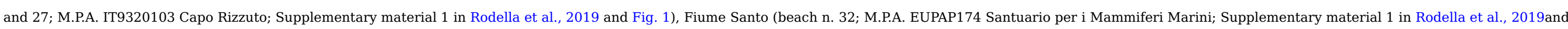
Fig. 1).

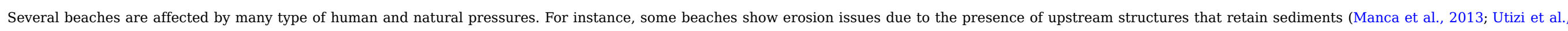
2016), subsidence (e.g. Adriatic coast; Simeoni et al., 2017a; Simeoni and Corbau, 2009), dune's damages (Corbau et al., 2015), storm surges and tides (Martinelli et al., 2010).

\section{Materials and methods}

\subsection{Beach characterization and typology}

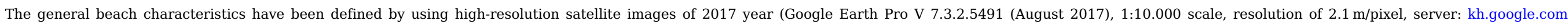

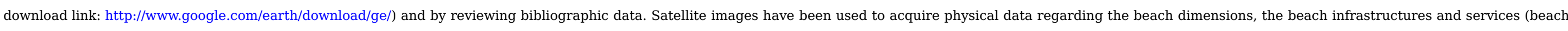
establishments, umbrellas, toilets, etc.), coastal defence and dune presence.

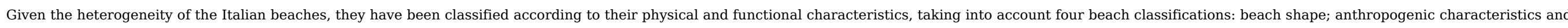
beach activity expressed by Williams and Micallef (2009); urbanization levels defined by Ariza et al. (2008) as reported in Supplementary material 1 in Rodella et al. (2019). 
The classification of Peña-Alonso et al. (2018) has been finally reviewed and adapted to the peculiarities of Italian beaches as reported in Table 1.

\subsection{Beach users'- perception, questionnaire and sampling}

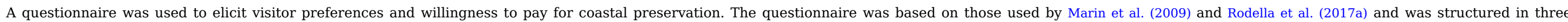
sections (Supplementary material 2 in Rodella et al., 2019):

- inquires about tourists' characteristics such as gender, age, educational level, employment status and place of residence as well as information about frequency and beach users' motivation;

- beach users are asked about their perception of physical and environmental featuress of the beach, including available services and equipments:

- examination of geomorphological problems, local management, the available surface per user, the coastal defence system and the willingness to pay for beach preservation.

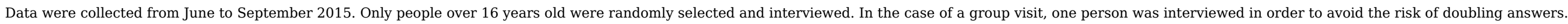
They were also informed that there was no right or wrong answer and their sincere responses would be appreciated.

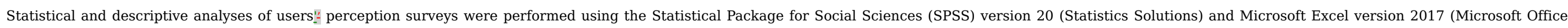
Redmond, Washington, USA).

\subsection{Contingent valuation and the experimental design}

A Contingent Valuation (CV) has been applied to all interviews in order to assess the tourist's WTP for beach protection and conservation.

\subsubsection{The model}

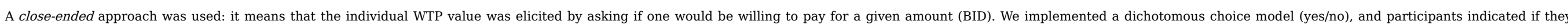
would or not be willing to pay the selected amount.

The WTP question was:

"In case that a financial fund is constituted in order to ensure the appropriate beach management, would you pay $X €$ (for person) each season in this territory?"

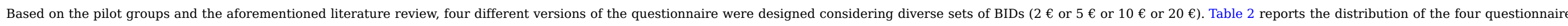
versions for each beach use typology.

Table 2 Questionnaire distribution in beach use typology in relation to the BID.

alt-text: Table 2

BID (€)

Natural (\%)

2.0

No answer

2

5

10

20

\section{Beach Type}

Semi-urban (\%)

\begin{tabular}{l|}
\hline 0.7 \\
\hline 24.3 \\
\hline 24.1 \\
\hline 27.0 \\
\hline 23.9 \\
\hline
\end{tabular}

Urban (\%)

\begin{tabular}{|l|l|}
\hline 2.2 & 1.9 \\
\hline 25.2 & 25.2 \\
\hline 23.4 & 23.8 \\
\hline 23.5 & 23.7 \\
\hline 25.7 & 25.4 \\
\hline
\end{tabular}

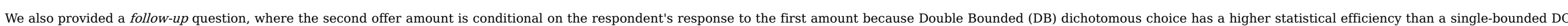




\subsubsection{The WTP estimation}

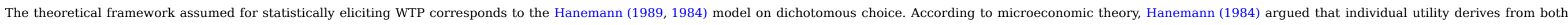
environmental good characteristics and own income.

Table 3 shows the model assumption adopted for WTP estimation.

\section{Table 3 Model assumption for WTP estimation.}

\section{alt-text: Table 3}

\section{Model Assumption}

Utility-function $\mathrm{U}(j, \mathrm{Y}, s)$, where $j$ is a dichotomous variable associated to the use of a given beach $(j=1$, use of the good; $j=0$, non-use of the good), $\mathrm{Y}$ is the individual income, $s$ is the socio-economic characteristics vector, $\mathrm{e}_{j}$ is the stochastic error term

An interviewer would respond YES to the provided question only in case of Eq. (2), where $\mathrm{x}_{i}$ is the formulated BID.

The probability distribution of the answer corresponds to Eq. (3)

$\eta=\mathrm{e}_{1}-\mathrm{e}_{0}, \mathrm{~F} \eta(\bullet)$ is the distribution function of $\eta$ and the term $\Delta v$ is equal to the difference

Assuming that $\mathrm{x}_{i} \leq \mathrm{WTP}$, the probability of accepting the proposed BID is Eq. (6), where $\mathrm{G}_{\mathrm{WTP}}(\bullet)$ is the accumulated distribution function of the random WTP Comparing (4) with (6), it derives a relationship between WTP and utility: Eq. (7)

In order to estimate WTP, we handle $\mathrm{F} \eta(\Delta v)$ as a logistic distribution function and, as a consequence, we adopt a logit model for describing the probability function Eq. (8), whereas we assume a linear model of the income, where utility is given by Eq. (9), where $\alpha_{j}$ is the constant term and $\beta$ represents the marginal utility of income.

If $\alpha=\alpha_{j}-\alpha_{0}$, it follows Eq. (10)

Matching (Eq. (10)) and (Eq. (8)) we obtain the logit-linear model that can be estimated by Maximum Log-likelihood Estimation (MLE)

McFadden and Leonard (1992) and Cooper and Loomis (1992) recommended to estimating the median WTP - better trend indicator than the average value from the univariate model (including only the BID as variable) and by applying Eq. (12)

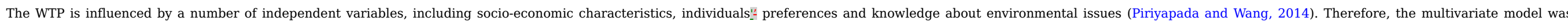
applied in order to estimate the role of socio-economic variables in conditioning WTP. The variables that were used are described in Table 4.

Table 4 Description of variables used in the multivariate model.

alt-text: Table 4

Equation

$\mathrm{u}(j, \mathrm{Y}, s)=\mathrm{v}(j, \mathrm{Y}, s)+\mathrm{e}_{j}(j=0,1)$

$\mathrm{v}\left(1, \mathrm{Y}-\mathrm{x}_{i}, s\right)+\mathrm{e}_{1} \geq \mathrm{v}(0, \mathrm{Y}, s)+\mathrm{e}_{0}$

$\operatorname{Prob}\left(\mathrm{YES} \mid \mathrm{x}_{i}\right)=\operatorname{Prob}\left[\mathrm{v}\left(1, \mathrm{Y}-\mathrm{x}_{i}, \mathrm{~s}\right)+\mathrm{e}_{1} \geq \mathrm{v}(0, \mathrm{Y}, s)+\mathrm{e}_{0}\right]$ (3)

$\operatorname{Prob}\left(\mathrm{YES} \mid \mathrm{x}_{i}\right)=\mathrm{F} \eta(\Delta v)$

$\Delta v=\mathrm{v}\left(1, \mathrm{Y}-\mathrm{x}_{i}, s\right)-\mathrm{v}(0, \mathrm{Y}, s)$

$\operatorname{Prob}(\mathrm{YES} \mid \mathrm{xi})=\operatorname{Prob}(\mathrm{WTP} \geq \mathrm{xi})=1-\mathrm{G}_{\mathrm{WTP}}(\mathrm{xi})$

$\mathrm{G}_{\mathrm{WTP}}\left(\mathrm{x}_{i}\right)=\mathrm{F} \eta(\Delta v)$

$\operatorname{Prob}\left(\mathrm{YES} \mid \mathrm{x}_{i}\right)=\mathrm{F} \eta(\Delta v)=\frac{1}{1+e^{-\Delta v}}$

$\mathrm{U}_{i}=\alpha_{j}-\beta \mathrm{Y}$

$\Delta v=\alpha+\beta \mathrm{x}_{i}$

$\operatorname{Prob}\left(\mathrm{YES} \mid \mathrm{x}_{i}\right)=\frac{1}{1+e^{-\left(\alpha-\beta x_{i}\right)}}$

$\mathrm{WTP}_{\text {median }}=\frac{\alpha}{-\beta}$ was 


\begin{tabular}{|c|c|c|}
\hline Variable & Abbreviation & Description \\
\hline \multicolumn{3}{|l|}{ Beach Shape } \\
\hline Linear beach & S1 & $1=$ Yes $; 0=$ otherwise \\
\hline Artificial & $\mathrm{S} 2$ & $1=$ Yes $; 0=$ otherwise \\
\hline Linear and Artificial & S3 & $1=$ Yes; $0=$ otherwise \\
\hline Pocket & S4 & $1=$ Yes; $0=$ otherwise \\
\hline \multicolumn{3}{|c|}{ Level of recreational services } \\
\hline \multirow[t]{3}{*}{ Activity } & \multirow[t]{3}{*}{ A } & $1=$ Recreation \\
\hline & & $2=$ Recreation $/$ Conservation \\
\hline & & $3=$ Conservation \\
\hline \multicolumn{3}{|c|}{ Level of urbanization } \\
\hline \multirow{3}{*}{ Urbanization } & \multirow{3}{*}{ C } & $1=$ Natural \\
\hline & & $2=$ Semi-Urban \\
\hline & & $3=$ Urban \\
\hline \multicolumn{3}{|c|}{ Gender of interviewed } \\
\hline \multirow[t]{2}{*}{ Gender } & \multirow[t]{2}{*}{ G } & $1=$ Male \\
\hline & & $0=$ Female \\
\hline \multicolumn{3}{|l|}{ Age of interviewed } \\
\hline Age & A & Continuous variable \\
\hline \multicolumn{3}{|c|}{ Level of education of interviewed } \\
\hline \multirow[t]{3}{*}{ Education } & \multirow[t]{3}{*}{$\mathrm{E}$} & $1=$ Under high school \\
\hline & & $2=$ High school \\
\hline & & $3=$ Degree or upper \\
\hline \multicolumn{3}{|c|}{ Residence of interviewed } \\
\hline \multirow[t]{2}{*}{ Residence } & \multirow[t]{2}{*}{$\mathrm{R}$} & $1=$ Resident \\
\hline & & $0=$ Non-resident \\
\hline \multicolumn{3}{|c|}{ Frequency of visiting } \\
\hline \multirow[t]{3}{*}{ Frequency } & \multirow[t]{3}{*}{$\mathrm{F}$} & $1=$ first time \\
\hline & & $2=$ other visits \\
\hline & & $3=$ frequent visitor \\
\hline
\end{tabular}

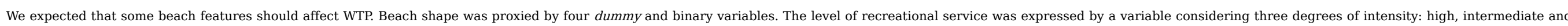
low (highly conserved environment). The level of urbanization was expressed by three ordinal variables: natural beaches, urbanized beaches and urban beaches.

On the socio-economic characteristics of tourists, we considered the gender, the level of education, and the age of person interviewed as well as their residence and their frequentation of the specific beach. 


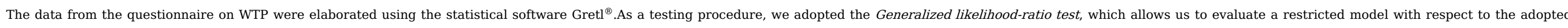
model (Bohrnstedt and Knoke, 1994). The statistic associated with this test is defined as:

$\mathrm{L}=-2 \ln \rrbracket=-2\left\lfloor\ln \frac{L\left(H_{0}\right)}{L\left(H_{1}\right)}\right\rfloor=-2[\ln \mathrm{L}(\mathrm{H} 0)-\ln \mathrm{L}(\mathrm{H} 1)]$

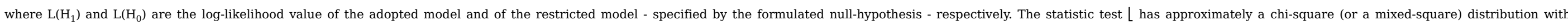

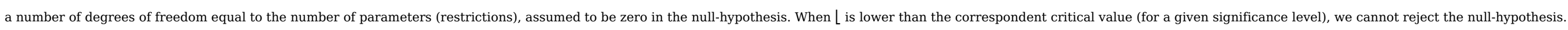

Specifically, the Generalized likelihood-ratio test was run to estimate suitability of the proposed model with respect to the restricted model without the constant term.

\section{Results}

\subsection{Beach typology and users':- perception}

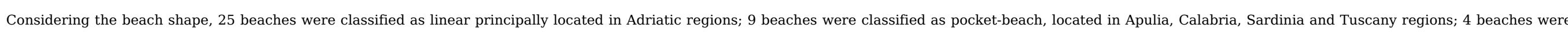
identified as artificial embayed beach; 3 as artificial embayed beach - linear. General characteristics of these records are given in the companion data article (Rodella et al., 2019).

The use typology classification identified 6 natural beaches, 7 semi-urban beaches and 28 urban beaches (Rodella et al., 2019).

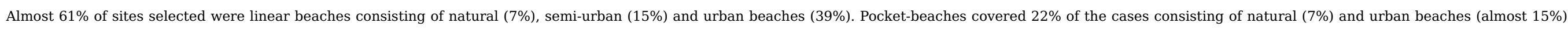
Artificial embayed beaches covered 10\% (2\% of semi-urban and $8 \%$ of urban beaches) and 7\% were artificial embayed - linear beaches (only urban typology) (Rodella et al., 2019).

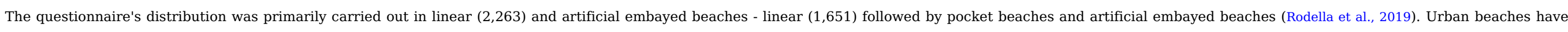
been surveyed through 3754 questionnaires while semi-urban and natural beaches were less surveyed (787 and 627 respectively; Rodella et al., 2019).

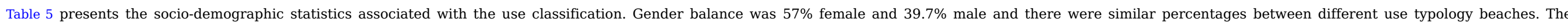

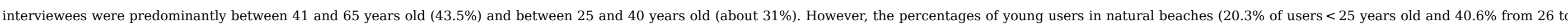

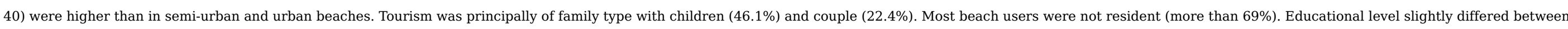

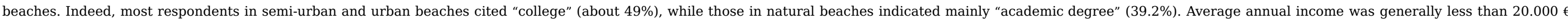
but $19.5 \%$ of the respondents did not reveal their income. Income did not vary regarding beaches (Table 5).

Table 5 General and individual sociodemographic characteristics, frequentation and reason for choosing the beach.

\section{alt-text: Table 5}

\begin{tabular}{|c|c|c|c|c|}
\hline & Natural (\%) & Semi-urban (\%) & Urban (\%) & Total (\%) \\
\hline \multicolumn{5}{|l|}{ Gender } \\
\hline Male & 41.1 & 44.7 & 38.6 & 39.7 \\
\hline Female & 57.8 & 53.4 & 57.5 & 57.0 \\
\hline No answer & 1.2 & 1.9 & 3.9 & 3.3 \\
\hline \multicolumn{5}{|c|}{ Age (years) } \\
\hline$<25$ & 20.3 & 19.9 & 17.8 & 18.3 \\
\hline $26-40$ & 40.6 & 35.2 & 29.6 & 31.2 \\
\hline $41-65$ & 38.1 & 39.2 & 44.9 & 43.5 \\
\hline$>65$ & 1.0 & 5.7 & 7.7 & 7.0 \\
\hline
\end{tabular}




\section{Educational level}

Secondary school

12.9

45.7

College

Academic degree

No answer

39.2

2.2

49.7

49.7

34.9

3.0

49.1

33.4

48.8

\section{Provenience}

Resident

Not resident

25.0

\begin{tabular}{|l}
25.0 \\
74.5
\end{tabular}

\begin{tabular}{|l|}
21.4 \\
78.5
\end{tabular}

78.5

0.5

0.1

1.5

34.3

1.8

No answer

48.3

Italian

48.3

Foreign

.3

91.3

51.3

1.1

No answer

1.7

23.5

38.2

33.6

2.6

7.6

Alone

With partner

Family with sons

19.2

19.2

54.9

Friends

Someone else

21.9

1.7

\begin{tabular}{|l|l|}
\hline 33.1 & 30.5 \\
\hline 66.6 & 69.2 \\
\hline 0.3 & 0.3 \\
\hline
\end{tabular}

\section{Annual Income ( $\boldsymbol{\epsilon} /$ year}

Lower than 20.000

30.0

From 20.000 to 31.000

From 31.000 to 41.000

27.8

13.2

10.8

More than 41.000

No answer

18.2

32.7

90.1

3.4

3.4

2.7

11.9

\section{Satisfaction of the holiday}

Yes

No

No answer

90.1

6.3

3.6

32.7

27.0

11.2

6.5

22.6

4.8

22.8

45.7

23.9

1.7

4.1

22.4

46.1

24.7

1.8

\section{First time on the beach?}

Yes

25.2

No, I have already come some time

No, I come here regularly

No answer

85.3

86.4

3.6

7.5

6.0

.7

\begin{tabular}{|l|l|l|}
\hline 21.5 & 13.1 & 15.7 \\
\hline 20.1 & 23.2 & 23.3 \\
\hline 56.8 & 60.4 & 58.3 \\
\hline 1.5 & 3.3 & 2.8 \\
\hline
\end{tabular}




\section{Duration of stay in the resort (day)}

\begin{tabular}{|c|c|c|c|c|}
\hline Only one & 12.4 & 9.8 & 12.1 & 11.8 \\
\hline From 2 to 7 & 26.0 & 23.2 & 17.8 & 19.5 \\
\hline From 8 to 15 & 23.5 & 24.1 & 16.5 & 18.4 \\
\hline More than 15 & 36.1 & 40.8 & 47.5 & 45.2 \\
\hline No answer & 2.0 & 2.1 & 6.1 & 5.1 \\
\hline \multicolumn{5}{|c|}{ Reasons for choosing the beach } \\
\hline Sea/beach & 66.9 & 45.9 & 44.9 & 47.6 \\
\hline Nature and landscape & 4.0 & 4.6 & 2.9 & 3.3 \\
\hline Cultural heritage & .5 & 1.7 & .9 & .9 \\
\hline Economic reasons & 1.0 & 1.8 & 2.0 & 1.8 \\
\hline Play sport/amusement & 2.8 & 1.8 & 1.0 & 1.4 \\
\hline Relax/quiet & 6.6 & 15.2 & 11.4 & 11.3 \\
\hline Have a holiday home & 10.1 & 11.2 & 13.4 & 12.7 \\
\hline Other & 7.6 & 17.0 & 22.2 & 19.8 \\
\hline No answer & 0.5 & 1.0 & 1.4 & 1.2 \\
\hline
\end{tabular}

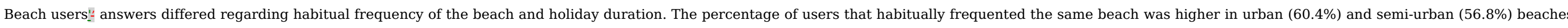

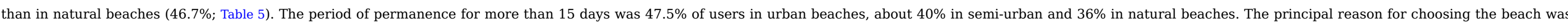

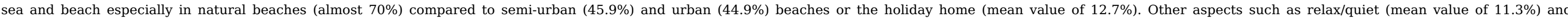
nature/landscape (mean value of 3.3\%) also played a role (Table 5).

\subsection{WTP}

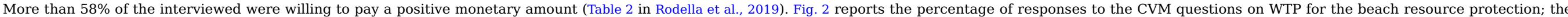

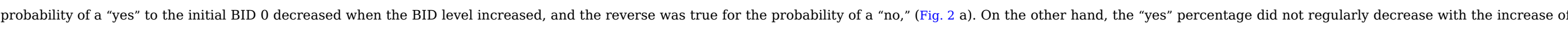
BID 1 in the follow-up question (Fig. 2 b). In particular, the highest positive answer was registered for $4 €(12.7 \%)$ and $10 €(13 \%)$, while the lower percentages were expressed for $1 €(1.5 \%)$ and $2.5 €(1.9 \%)$.
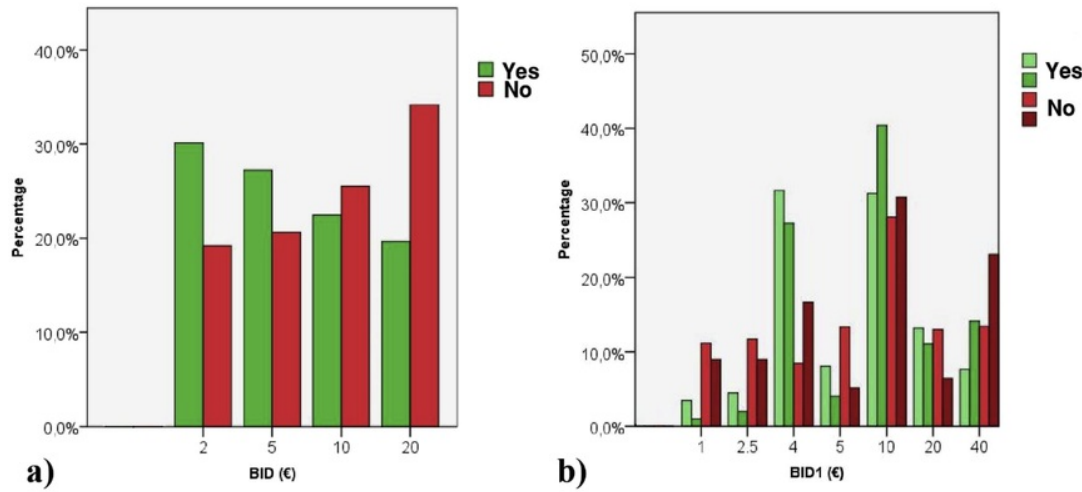

a)

BID (6)

b)

Yes

No 


\section{alt-text: Fig. 2}

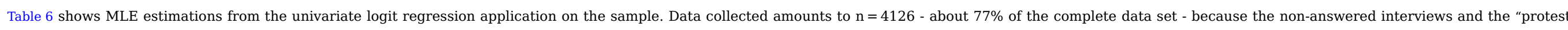

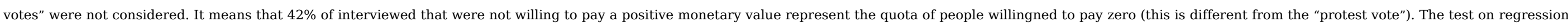

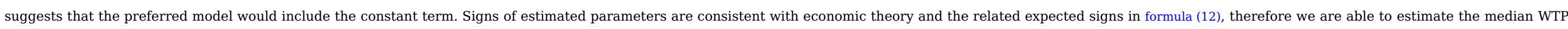
to be $14.84 €$ (Table 6).

Table 6 WTP results. Estimation of the dichotomous logit model (single bounded) - follow up model (number of records = 4126) (S.E.: Standard Error; z: z-Statistic; D.F.: Degree of Freedom). alt-text: Table 6

\begin{tabular}{|c|c|c|c|c|c|}
\hline \multicolumn{2}{|c|}{ Variables } & \multirow[t]{2}{*}{ Coefficient } & \multirow[b]{2}{*}{0.054} & \multirow[b]{2}{*}{15.31} & \multirow[t]{2}{*}{$\mathrm{p}$-value } \\
\hline Constant & $\alpha$ & & & & \\
\hline BID & $\beta$ & -0.056 & 0.004 & -12.19 & $0.000^{* * *}$ \\
\hline \multicolumn{6}{|c|}{ Test on regression } \\
\hline LL value & $L^{\prime}$ value $^{a}$ & $\chi^{2}$ & D.F. & $\chi^{2}(0.95)$ & p-value \\
\hline-2737.73 & -2859.88 & 244.3 & 1 & 3.84 & 0.000 \\
\hline
\end{tabular}

\section{Median $W T P=14.84 €$}

a Alternative model without the constant term.

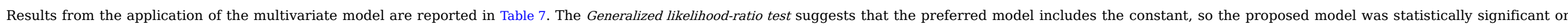

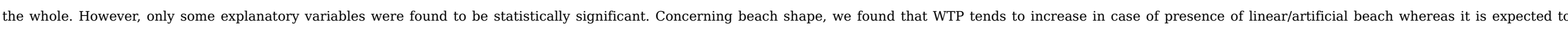

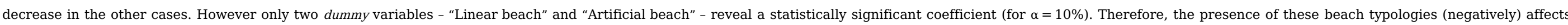
the WTP, instead mixed typology positively done ("Pocket beach" is a redundant variable because it is expressed as residual with respect to the other dummy variables").

Table 7 Estimation of the dichotomous multinomial logit model (number of records = 4126) (S.E.: Standard Error; z: z-Statistic; D.F.: Degree of Freedom). alt-text: Table 7

\begin{tabular}{|c|c|c|c|c|c|}
\hline Variables & Abbreviation & Coeff. & S.E. & $\mathrm{z}$ & p-value \\
\hline Constant & $\alpha$ & 1.951 & 0.479 & 4.073 & $0.000^{* * *}$ \\
\hline BID & $\beta$ & -0.056 & 0.005 & -11.946 & $0.000^{* * *}$ \\
\hline Use & $\mathrm{U}$ & -0.261 & 0.168 & -1.555 & $0.120^{a}$ \\
\hline Urbanization & C & -0.190 & 0.081 & -2.356 & $0.019 * *$ \\
\hline Gender & G & 0.163 & 0.066 & 2.454 & $0.014^{* *}$ \\
\hline Age & A & 0.005 & 0.002 & 2.287 & $0.022 * *$ \\
\hline Education & $\mathrm{E}$ & -0.011 & 0.047 & -0.236 & 0.815 \\
\hline Residence & $\mathrm{R}$ & -0.116 & 0.072 & -1.611 & 0.106 \\
\hline Frequency & $\mathrm{F}$ & -0.002 & 0.030 & -0.067 & 0.973 \\
\hline
\end{tabular}




\begin{tabular}{|c|c|c|c|c|c|}
\hline$L L$ value & $L L^{\prime}$ value $^{\mathrm{a}}$ & $\chi^{2}$ & D.F. & $\chi^{2}(0.95)$ & p-value \\
\hline-2719.27 & -2813.22 & 187.9 & 1 & 3.84 & 0.000 \\
\hline
\end{tabular}

a Alternative model without the constant term.

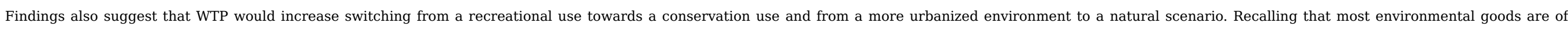

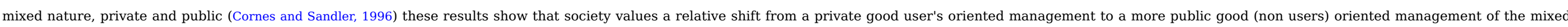

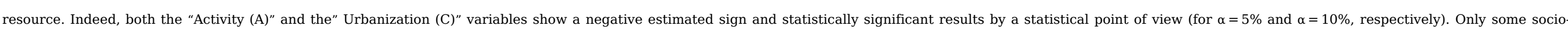

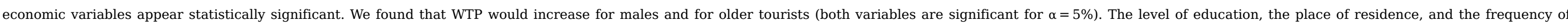
visiting the observed beach do not appear statistically significant (data of demographic statistics are reported in Rodella et al., 2019).

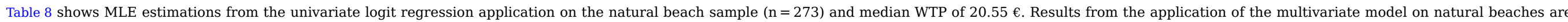

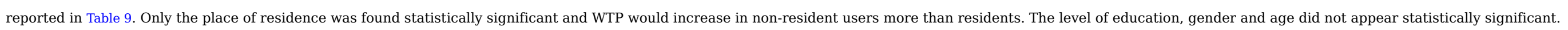

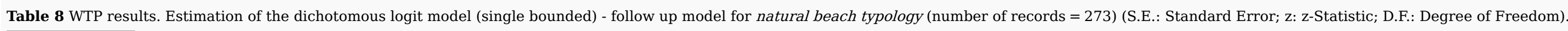
alt-text: Table 8

\begin{tabular}{|c|c|c|c|c|c|}
\hline \multicolumn{2}{|c|}{ Variables } & \multirow[t]{2}{*}{ Coefficient } & \multirow[b]{2}{*}{0.213} & \multirow[b]{2}{*}{4.25} & \multirow[t]{2}{*}{$\mathrm{p}$-value } \\
\hline Constant & $\alpha$ & & & & \\
\hline BID & $\beta$ & -0.044 & 0.018 & -2.49 & $0.013^{* * *}$ \\
\hline \multicolumn{6}{|c|}{ Test on regression } \\
\hline LL value & $L L^{\prime} v^{\prime}$ alue $e^{a}$ & $\chi^{2}$ & D.F. & $\chi^{2}(0.95)$ & p-value \\
\hline-178.29 & -181.45 & 6.32 & 1 & 3.84 & 0.000 \\
\hline
\end{tabular}

Median $W T P=20.55 €$

a Alternative model without the constant term.

Table 9 Estimation of the dichotomous multinomial logit model for natural beach typology (number of records = 273) (S.E.: Standard Error; z: z-Statistic; D.F.: Degree of Freedom). alt-text: Table 9

\begin{tabular}{|c|c|c|c|c|c|}
\hline \multicolumn{2}{|c|}{ Variables } & \multirow[t]{2}{*}{ Coefficient } & \multirow[b]{2}{*}{1.037} & \multirow[b]{2}{*}{2.965} & \multirow[b]{2}{*}{$0.003^{* * *}$} \\
\hline Constant & $\alpha$ & & & & \\
\hline BID & $\beta$ & -0.048 & 0.018 & -2.667 & $0.010^{* *}$ \\
\hline Gender & G & -0.207 & 0.264 & -0.784 & 0.431 \\
\hline Age & A & 0.015 & 0.010 & 1.500 & 0.120 \\
\hline Education & $\mathrm{E}$ & -0.100 & 0.195 & -0.513 & 0.606 \\
\hline Residence & $\mathrm{R}$ & $-\mathbf{1 . 1 5 7}$ & 0.398 & -2.907 & $0.004^{* * *}$ \\
\hline \multicolumn{6}{|c|}{ Test on regression } \\
\hline$L L$ value & $L L^{\prime} v^{\prime} a^{\prime} e^{\mathrm{a}}$ & $\chi^{2}$ & g. libertà & $\chi^{2}(0.95)$ & p-value \\
\hline-172.46 & -181.41 & 17.90 & 1 & 3.84 & 0.000 \\
\hline
\end{tabular}


a Alternative model without the constant term.

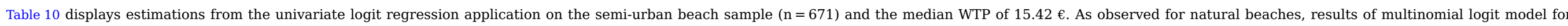

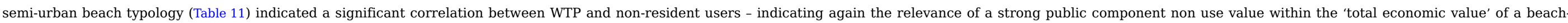
and, in addition, a correlation with the age variable.

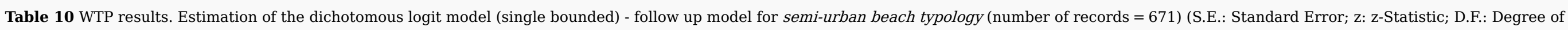
Freedom).

\section{alt-text: Table 10}

\begin{tabular}{|c|c|c|c|c|c|}
\hline \multicolumn{2}{|c|}{ Variables } & Coefficient & S.E. & $\mathrm{z}$ & $\mathrm{p}$-value \\
\hline Constant & $\alpha$ & 0.555 & 0.132 & 4.19 & $0.000^{* * *}$ \\
\hline BID & $\beta$ & -0.036 & 0.011 & -3.11 & $0.002 * * *$ \\
\hline \multicolumn{6}{|c|}{ Test on regression } \\
\hline$L L$ value & $L^{\prime}$ value $^{\mathrm{a}}$ & $\chi^{2}$ & D.F. & $\chi^{2}(0.95)$ & p-value \\
\hline-456.01 & -460.88 & 9.74 & 1 & 3.84 & 0.000 \\
\hline
\end{tabular}

a Alternative model without the constant term.

Table 11 Estimation of the dichotomous multinomial logit model for semi-urban beach typology (number of records = 671) (S.E.: Standard Error; z: z-Statistic; D.F.: Degree of Freedom). alt-text: Table 11

\begin{tabular}{|c|c|c|c|c|c|}
\hline \multicolumn{2}{|c|}{ Variables } & \multirow[t]{2}{*}{ Coefficient } & \multirow[t]{2}{*}{ S.E. } & \multirow[b]{2}{*}{2.362} & \multirow[t]{2}{*}{$\mathrm{p}$-value } \\
\hline Constant & $\alpha$ & & & & \\
\hline BID & $\beta$ & -0.034 & 0.012 & -2.833 & $0.003^{* * *}$ \\
\hline Gender & G & -0.255 & 0.160 & -1.594 & 0.109 \\
\hline Age & $\mathrm{A}$ & 0.010 & 0.005 & 2.000 & $0.040^{* *}$ \\
\hline Education & $\mathrm{E}$ & -0.065 & 0.117 & -0.556 & 0.582 \\
\hline Residence & $\mathrm{R}$ & -0.365 & 0.198 & -1.843 & $0.065^{\mathrm{a}}$ \\
\hline \multicolumn{6}{|c|}{ Test on regression } \\
\hline$L L$ value & $\boldsymbol{L L}^{\prime}$ value $^{\mathrm{a}}$ & $\chi^{2}$ & D.F. & $\chi^{2}(0.95)$ & p-value \\
\hline-449.71 & -460.89 & 22.36 & 1 & 3.84 & 0.000 \\
\hline
\end{tabular}

a Alternative model without the constant term.

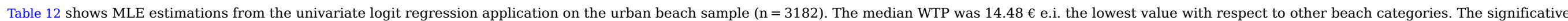
socio-demographic variable observed in the multinomial logit model was age variable (Table 13), as also verified for the semi-urban beaches (Table 11) and in the national sample (Table 7).

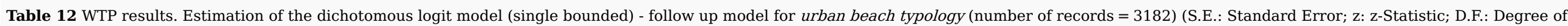




\begin{tabular}{|c|c|c|c|c|c|}
\hline \multicolumn{2}{|c|}{ Variables } & \multirow[t]{2}{*}{ Coefficient } & \multirow[b]{2}{*}{0.062} & \multirow[b]{2}{*}{14.23} & \multirow[b]{2}{*}{$0.000^{* * *}$} \\
\hline Constant & $\alpha$ & & & & \\
\hline BID & $\beta$ & -0.061 & 0.005 & -11.69 & $0.000^{* * *}$ \\
\hline \multicolumn{6}{|c|}{ Test on regression } \\
\hline$L L$ value & $L^{\prime} \boldsymbol{L}^{\prime} \operatorname{value}^{\mathrm{a}}$ & $\chi^{2}$ & D.F. & $\chi^{2}(0.95)$ & p-value \\
\hline-2099.49 & -2169.87 & 140.76 & 1 & 3.84 & 0.000 \\
\hline
\end{tabular}

\section{Median WTP $=14.48 €$}

a Alternative model without the constant term.

Table 13 Estimation of the dichotomous multinomial logit model for urban beach typology (number of records = 3182) (S.E.: Standard Error; z: z-Statistic; D.F.: Degree of Freedom). alt-text: Table 13

\begin{tabular}{|c|c|c|c|c|c|}
\hline \multicolumn{2}{|c|}{ Variables } & \multirow[t]{2}{*}{ Coefficient } & S.E. & $\mathrm{z}$ & $\mathrm{p}$-value \\
\hline Constant & $\alpha$ & & 0.243 & 3.362 & $0.000 * * *$ \\
\hline BID & $\beta$ & -0.061 & 0.005 & -13.062 & $0.000 * * *$ \\
\hline Gender & G & -0.087 & 0.075 & -1.160 & 0.243 \\
\hline Age & A & 0.005 & 0.002 & 2.423 & $0.047^{* *}$ \\
\hline Education & $\mathrm{E}$ & 0.009 & 0.053 & 0.170 & 0.860 \\
\hline Residence & $\mathrm{R}$ & -0.006 & 0.077 & -0.078 & 0.936 \\
\hline \multicolumn{6}{|c|}{ Test on regression } \\
\hline$L L$ value & $L L^{\prime}$ value $^{\mathrm{a}}$ & $\chi^{2}$ & D.F. & $\chi^{2}(0.95)$ & $\mathrm{p}$-value \\
\hline-2096.11 & -2169.30 & 146.38 & 1 & 3.84 & 0.000 \\
\hline
\end{tabular}

a Alternative model without the constant term.

\section{Discussion}

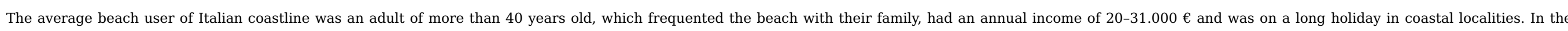

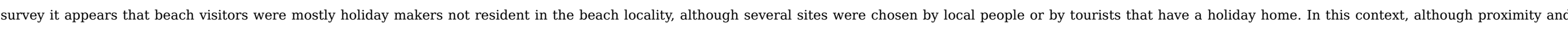

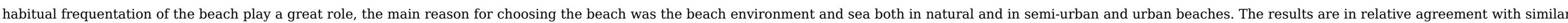

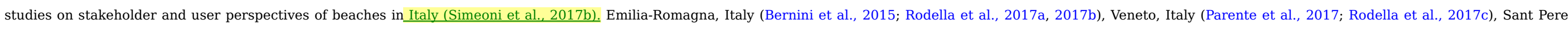
Pescador, Costa Brava, Spain (Lozoya et al., 2014), the Caribbean coast of Colombia (Botero et al., 2013), England and Wales (Tudor and Williams, 2006; Morgan et al., 1993).

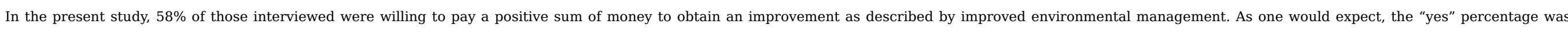

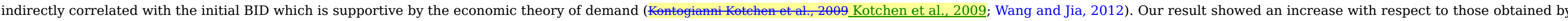

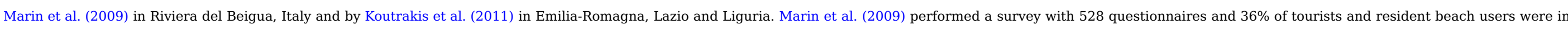

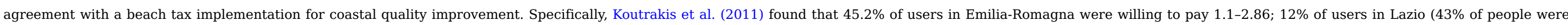




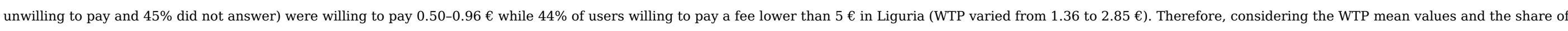

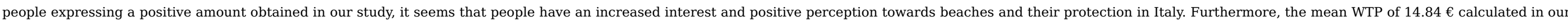

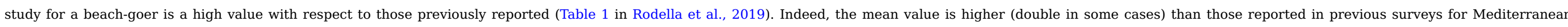

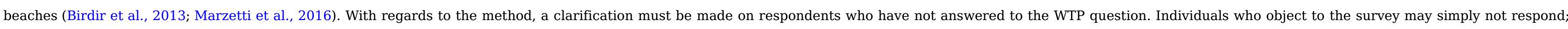

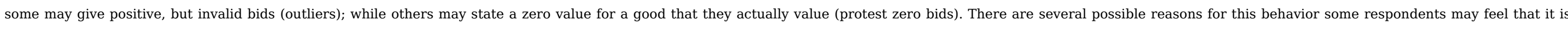

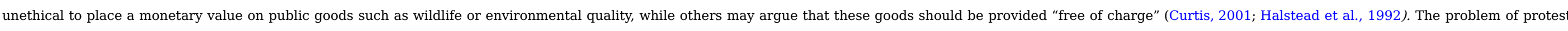

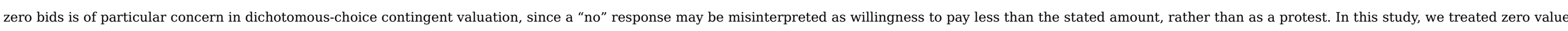

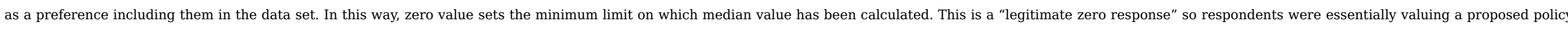

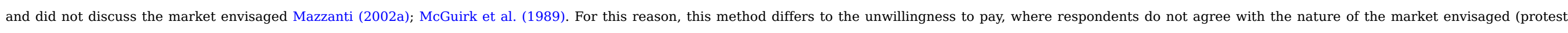
vote).

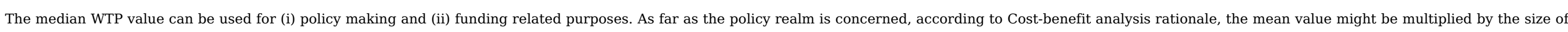

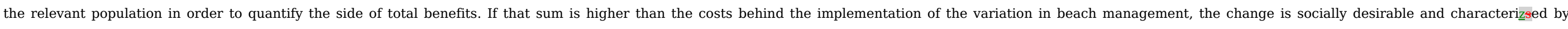

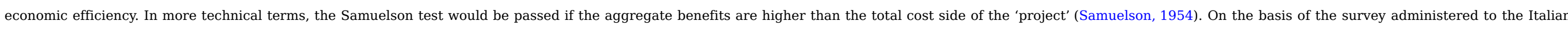

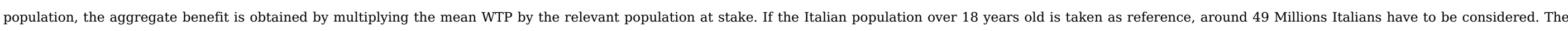

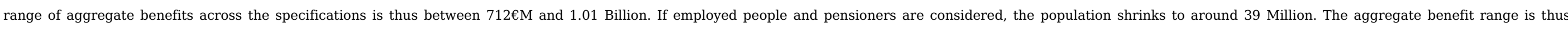
between 564 and $801 \mathrm{M} €$. Those figures have to compared to the costs of implementing the projects to improve the beach management.

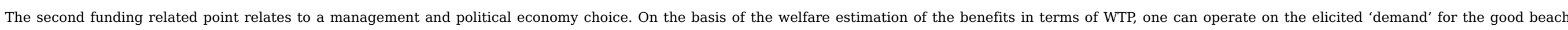

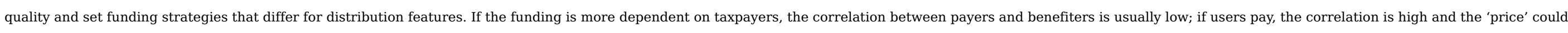

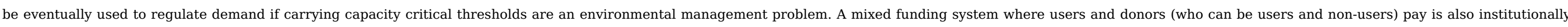
and economically sound: it bears less on users, it diversifies the funding participation, and it possibly extends demand in situ by lowering the potential price paid by users on the beach.

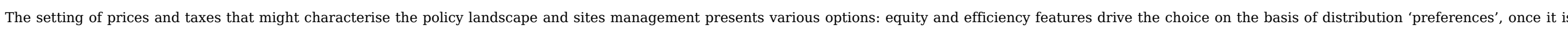

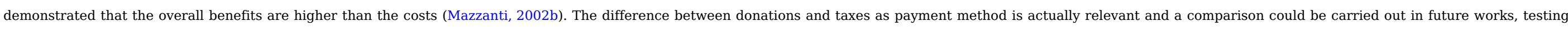

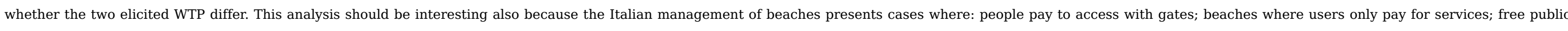
spaces on the beaches. Therefore, beachgoers are familiar with different ways of beach management and payment and to date a predominant one does not really exist.

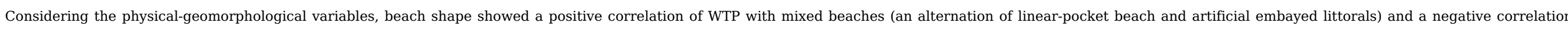

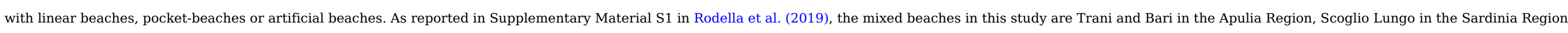

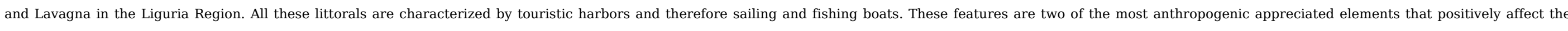

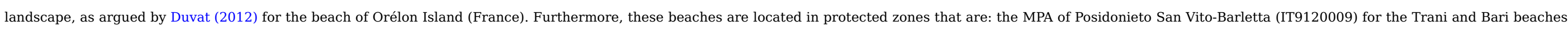

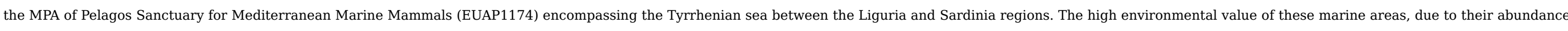
and biodiversity of species, probably affected the users:- WTP of these beaches.

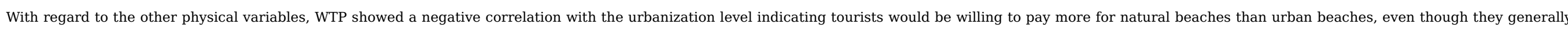

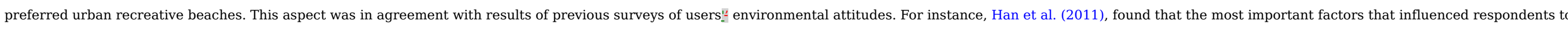

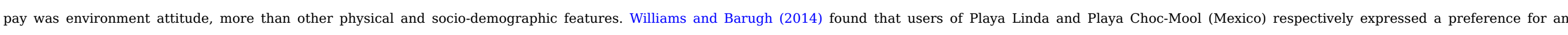

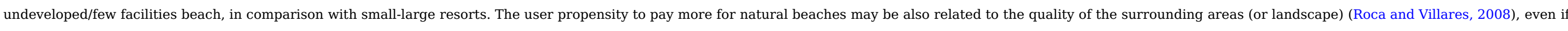

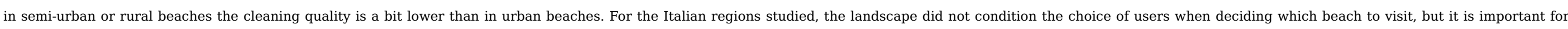
global assessment and therefore to WTP. 


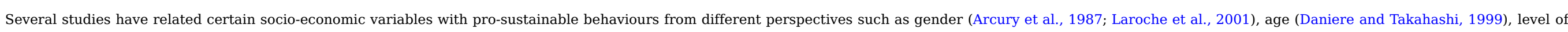

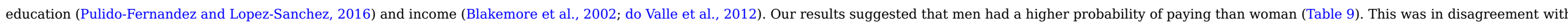

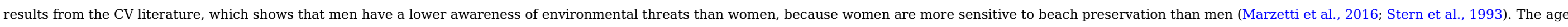

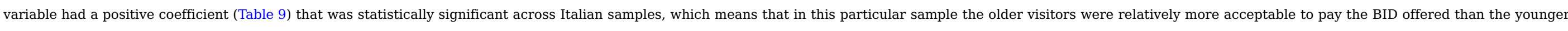

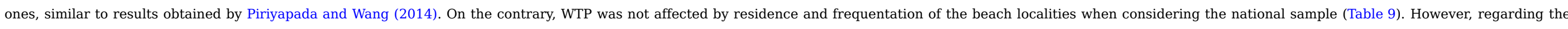

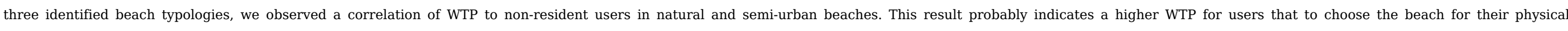

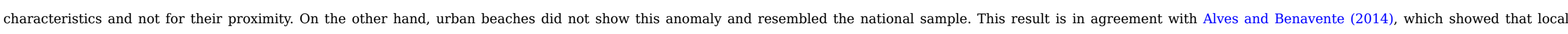

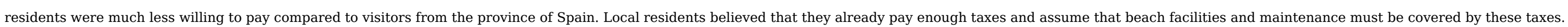

\section{Conclusions}

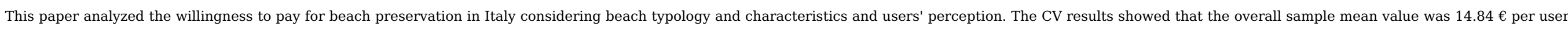

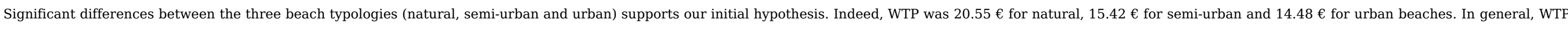

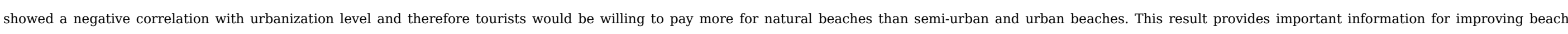

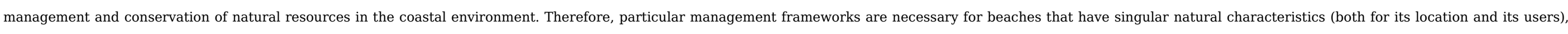
and especially for those located in traditional tourist areas.

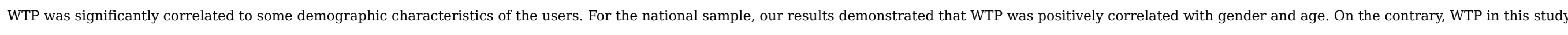

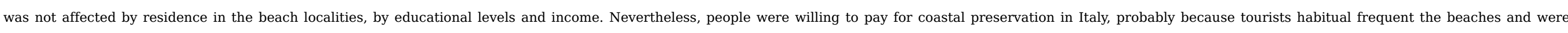

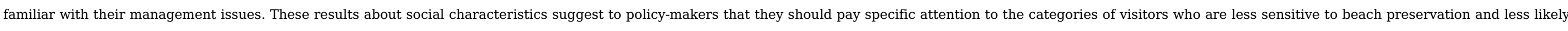
to pay.

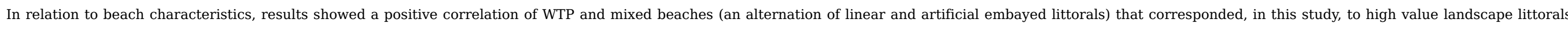
characterized by both physical and heritage features. On the other hand, artificial embayed beaches and linear beaches with high urbanization level showed a negative correlation with WTP.

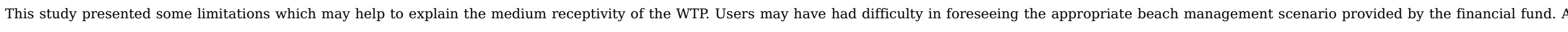

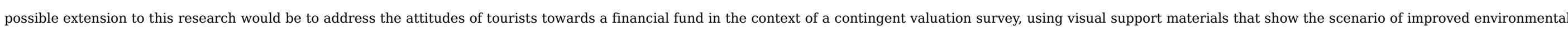

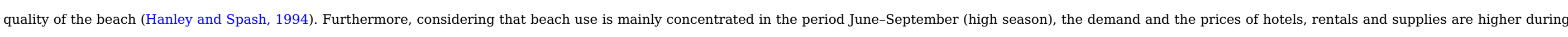

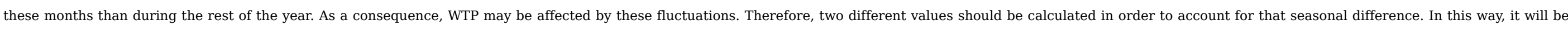
possible to obtain data about beach economics for the entire year (i.e. bathing and non-bathing season).

\section{Funding}

This research did not receive any specific grant from funding agencies in the public, commercial, or not-for-profit sectors.

\section{Uncited references}

Ariza al., 2012; Billé, 2007; Simeoni et al., 2017b.

\section{Acknowledgements}

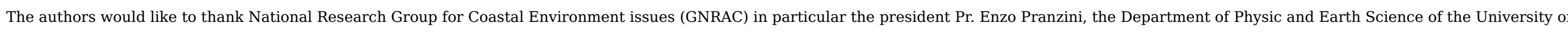

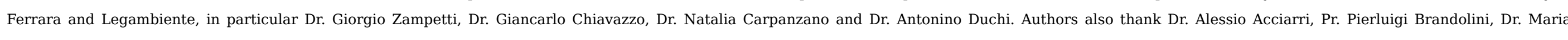

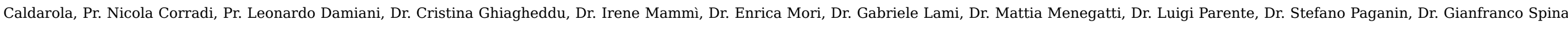
Iaconis, Dr. Antonio Trivisani. We thank the two anonymous reviewers for their comments and suggestions. 


\section{References}

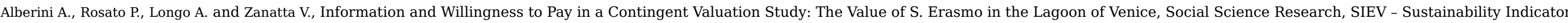
and Environmental Valuation, 2004, 38, Venezia.

Almansa C., Calatrava J. and Martínez-Paz J.M., Extending the framework of the economic evaluation of erosion control actions in Mediterranean basins, Land Use Policy 29, 2012, 294-308,

https://doi.org/10.1016/j.landusepol.2011.06.013.

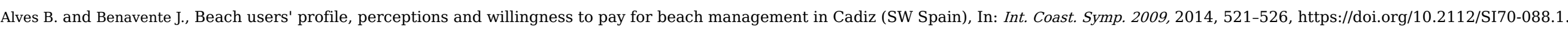

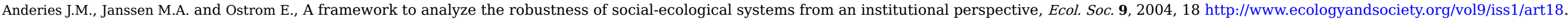

Arcury T.A., Scollay S.J. and Johnson T.P., Sex differences in environmental concern and knowledge: The case of acid rain, Sex. Roles 16, 1987, 463-472, https://doi.org/10.1007/BF00292481.

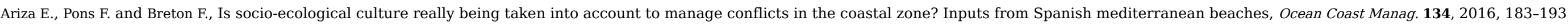
https://doi.org/10.1016/j.ocecoaman.2016.10.006

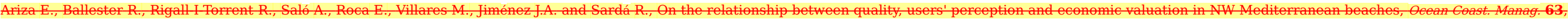

2012, 55-66, https.//doi.org/10.1016/j.ocecoaman.2012.04.002

Ariza E., Jimenez J.A. and Sarda R., Proposal for an Integral Quality Index for Urban and Urbanized Beaches, Environ. Manag. 45, 2010, 998 https://doi.org/10.1007/s00267-010-9472-8.

Ariza E., Jiménez J.A. and Sardá R., A critical assessment of beach management on the Catalan coast, Ocean Coast. Manag. 51, 2008, 141-160, https://doi.org/10.1016/j.ocecoaman.2007.02.009. Atkinson G. and Mourato S., Cost-Benefit Analysis and the Environment, OECD Environment Working Papers, No. 972015, OECD Publishing; Paris https://doi.org/10.1787/5jrp6w76tstg-en.

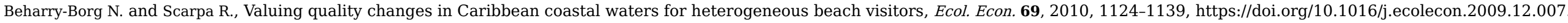
Bell F.W., Economic policy issues associated with beach nourishment, Policy Stud. Rev. 6, 1986, 374-381.

Bernini C., Urbinati E. and Vici L., Visitor expectations and perceptions of sustainability in a mass tourism destination, 2015, Bologna University, 01/2015 www.turismo.unibo.it. Billé R., $\Lambda$ dual level framework for ovaluating integrated coastal management beyond labels, ocean Coast. Mamag. 50, 2007, 796 807 http://doi.org/10.1016/j.0cecoaman.2007.01.002.

Birdir S., Ünal Ö., Birdir K. and Williams A.T., Willingness to pay as an economic instrument for coastal tourism management: Cases from Mersin, Turkey, Tourism Manag. 36, 2013, 279-283, https://doi.org/10.1016/j.tourman.2012.10.020.

Blakemore F.B., Williams A.T., Unal O., Coman C. and Micallef A., A Comparison of Tourist Evaluation of Beaches in Malta, Romania and Turkey, World Leis. J. 44, 2002, 29-41,

https://doi.org/10.1080/04419057.2002.9674268.

Bohrnstedt G.W. and Knoke D., Statistics for Social Data Analysis, 1994, F.E. Peacock Publishers Inc.; Itasca.

Bombana B. and Ariza E., Clarifying some assumptions of coastal management: Analysis of values and uncertainties embedded in beach quality indexes, Ecol. Indicat. 91, $2018,376-385$.

Botero C., Pereira C., Tosic M. and Manjarrez G., Design of an index for monitoring the environmental quality of tourist beaches from a holistic approach, Ocean Coast. Manag. 108, 2015, 65-73 https://doi.org/10.1016/j.ocecoaman.2014.07.017

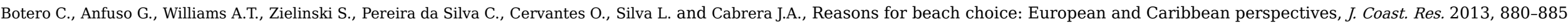
https://doi.org/10.2112/SI65-149.1.

Botero C. and Hurtado Y., Tourist Beach Sorts as a Classification Tool for Integrated Beach Management in Latin America, Int. Approaches Coast. Res. Theory Pract. Coastline Rep. 13, 2009, 133-142 
https://ssrn.com/abstract=2015612.

Chang J.-I. and Yoon S., Assessing the economic value of beach restoration: Case of Song-do Beach, Korea, J. Coast. Res. 79, 2017, 6-10, https://doi.org/10.2112/SI79-002.1.

Cooper J. and Loomis J., Sensitivity of Willingness-to-pay to BID Design in Dichotomous Choice Contingent Valuation Models, Land Econ. 68, 1992, $221-224$.

Corbau C., Simeoni U., Melchiorre M., Rodella I. and Utizi K., Regional variability of coastal dunes observed along the Emilia-Romagna littoral, Italy. Aeolian Res. 18, 2015, 169-183

http://doi.org/10.1016/j.aeolia.2015.07.001.

Cornes R. and Sandler T., The Theory of Externalities, Public Goods and Club Good, 1996, Cambridge University Press; Cambridge.

Curtis J.A., The Use of Follow-Up Questions to No Responses in Dichotomous Choice Contingent Valuation Surveys, Agric. Resour. Econ. Rev. 30, $2001,189-197$.

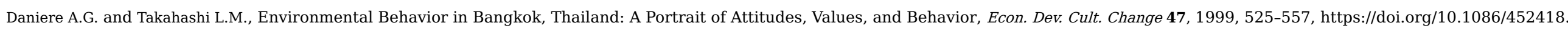

Diamond P.A. and Hausman J.A., Contingent Valuation: Is some number better than no number?, J. Econ. Perspect. 8, 1994, 45-64.

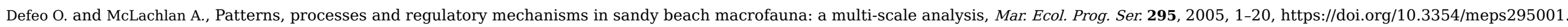

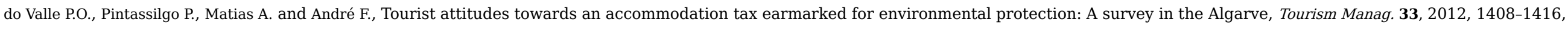

https://doi.org/10.1016/j.tourman.2012.01.003.

Duvat V., Public perception of beach quality: lessons learnt from a French case study, HAL Archives-ouvertes 2012 http://hal.archives-ouvertes.fr/hal-00821861.

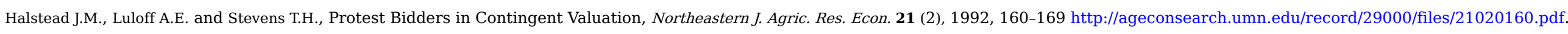

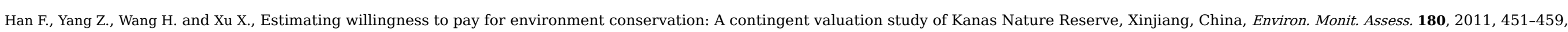

https://doi.org/10.1007/s10661-010-1798-4.

Hanemann W.M., Welfare Evaluations in Contingent Valuation Experiments with Discrete Responses: Reply, Am. J. Agric. Econ. 71, 1989, 1057-1061.

Hanemann W.M., Welfare Evaluations in Contingent Valuation Experiments with Discrete Responses, Am. J. Agric. Econ. 66, $1984,332-341$.

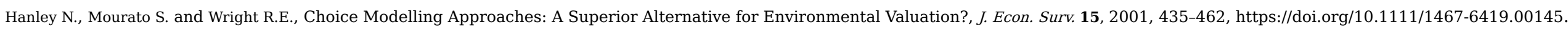

Hanley N. and Spash C., Cost-benefit analysis and the environment, 1994, Edward Elgar Pub; Cheltenham, UK.

Hicks J.R., Value and Capital: An Inquiry into Some Fundamental Principles of Economic Theory, 1939, Oxford University Press; New York.

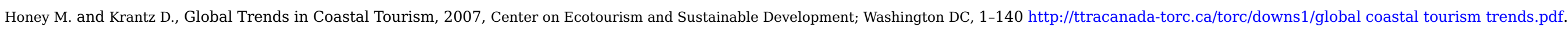

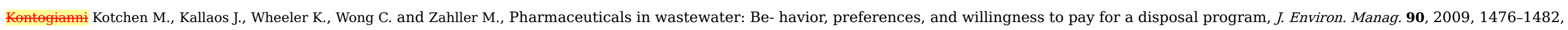

https://doi.org/10.1016/j.jenvman.2008.10. 002.

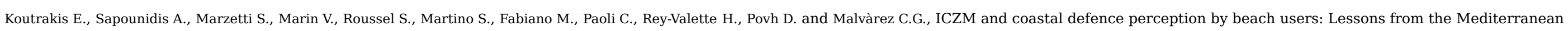
coastal area, Ocean Coast. Manag. 54, 2011, 821-830, https://doi.org/10.1016/j.ocecoaman.2011.09.004.

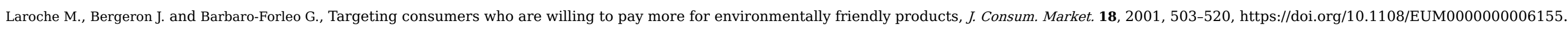

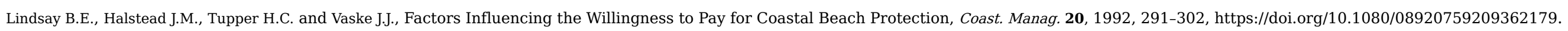

Liu X., Wirtz K.W., Kannen A. and Kraft D., Willingness to pay among households to prevent coastal resources from polluting by oil spills: A pilot survey, Mar. Pollut. Bull. 58, 2009, 1514-1521, 
https://doi.org/10.1016/j.marpolbul.2009.05.015.

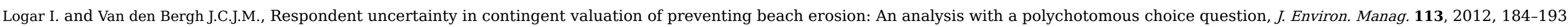
https://doi.org/10.1016/j.jenvman.2012.08.012.

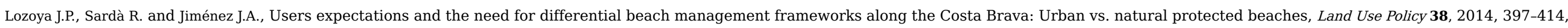
https://doi.org/10.1016/j.landusepol.2013.12.001.

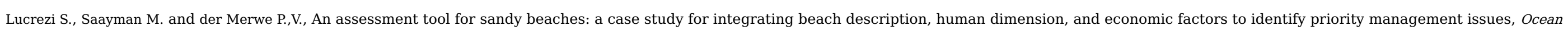
Coast Manag. 121, 2016, 1-22 https://doi.org/10.1016/j.ocecoaman.2015.12.003.

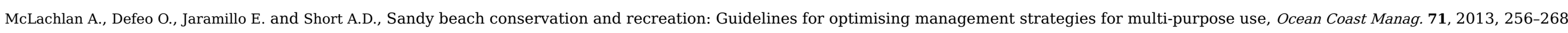
http://doi.org/10.1016/j.ocecoaman.2012.10.005.

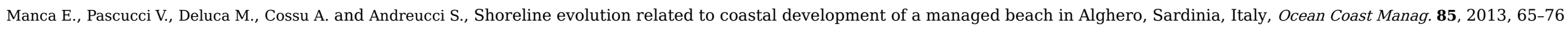
http://doi.org/10.1016/j.ocecoaman.2013.09.008.

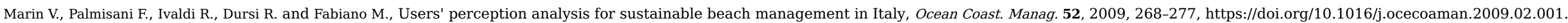

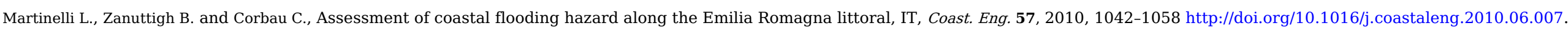

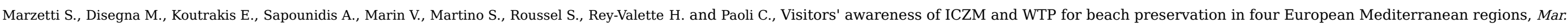
Policy 63, 2016, 100-108, https://doi.org/10.1016/j.marpol.2015.10.005.

Matthews Y., Scarpa R. and Marsh D., Stability of Willingness-to-Pay for Coastal Management: A Choice Experiment Across Three Time Periods, Ecol. Econ. 138, 2017, 64-73,

https://doi.org/10.1016/j.ecolecon.2017.03.031.

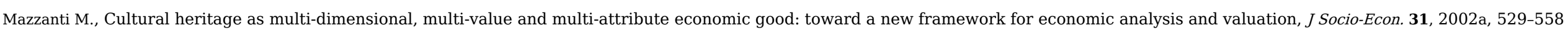
https://doi.org/10.1016/S1053-5357(02)00133-6.

Mazzanti M., Tourism Growth and Sustainability. A Note on Economic Issues, Tourism Econ. 8, 2002b, 457-462.

Mcconnell K.E., Congestion and Willingness to Pay: A Study of Beach Use, Land Econ. 53, 1977, 185-195, https://doi.org/10.2307/3145923.

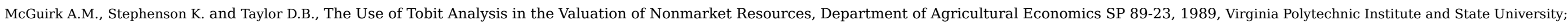
Blacksburg, VA.

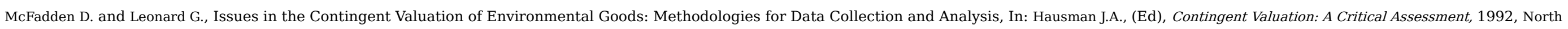
Holland Press; Amsterdam.

Micallef A. and Williams A.T., Theoretical strategy considerations for beach management, Ocean Coast. Manag. 45, 2002, 261-275.

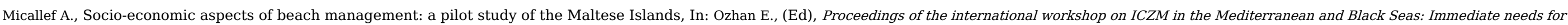
research, education, training and implementation, 1996, Middle East Technical University Press; Ankara, 111-124.

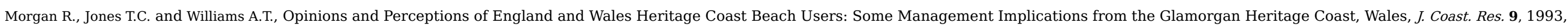
1083-1093.

Ozdemiroglu E. and Hails R., Demystifying Economic Valuation, Valuing Nature Paper VNP04, 2016 http://valuing-nature.net/demystifying-economic-valuation-paper. 
Parente L., Rodella I. and Simeoni U., La percezione dell'offerta turistico-balneare di due spiagge del Veneto: Lido di Venezia (VE) e Rosolina Mare (RO), Studi Costieri 25, 2017, 25-38 http://www.gnrac.unifi.it/rivista/Numero25/Articolo2.pdf.

Pearce D., Atkinson G. and Mourato S., Cost-benefit analysis and the environment: recent developments, 2006, OECD - Organization for Economic Co-Operation and Development Publishing; Paris.

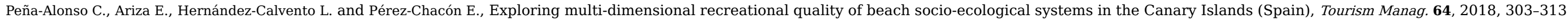
http://doi.org/10.1016/j.tourman.2017.09.008.

Peng M. and Oleson K.L.L., Beach Recreationalists' Willingness to Pay and Economic Implications of Coastal Water Quality Problems in Hawaii, Ecol. Econ. 136, 2017, 41-52,

https://doi.org/10.1016/j.ecolecon.2017.02.003.

Piriyapada S. and Wang E., Modeling Willingness to Pay for Coastal Tourism Resource Protection in Ko Chang Marine National Park, Thailand, Asia Pac. J. Tourism Res. 1665, 2014, 1-26,

https://doi.org/10.1080/10941665.2014.904806.

Pulido-Fernandez J. and Lopez-Sanchez Y., Are tourists really willing to pay more for sustainable destinations?, Sustainability 8, 2016, 1240, https://doi.org/10.3390/su8121240.

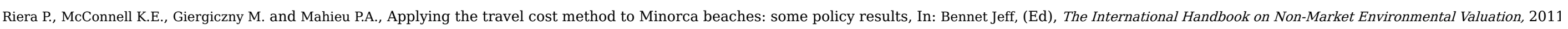
Edward Elgar Pub, 398.

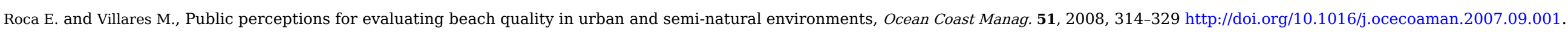

Rodella I., Madau F., Mazzanti M., Corbau C., Carboni D., Utizi K. and Simeoni U., Data for the analysis of willingness to pay of Italian beaches, Data in Brief 2019, (in press).

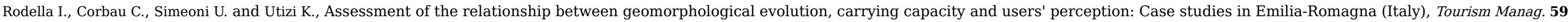
2017a, 7-22, https://doi.org/10.1016/j.tourman.2016.07.009.

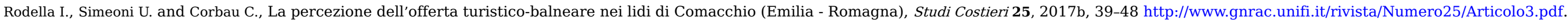

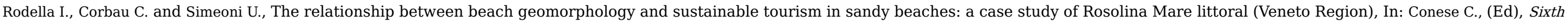
International Symposium "Monitoring of Mediterranean Coastal Areas: Problems and Measurement Techniques, 2017c, FUP; Firenze, 275-284.

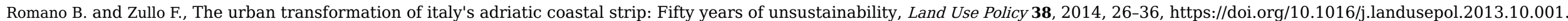

Samuelson P.A., The Pure Theory of Public Expenditure, Rev. Econ. Stat.. 36, 1954, 387-389.

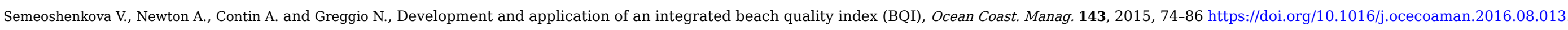

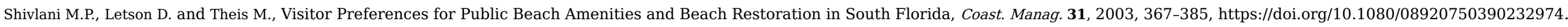

Silberman J. and Klock M., The recreation benefits of beach renourishment, Ocean Shorel. Manag. 11, 1988, 73-90, https://doi.org/10.1016/0951-8312(88)90006-9.

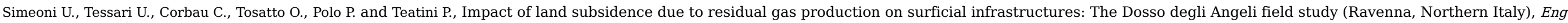
Geol. 229, 2017a, 1-12 https://doi.org/10.1016/j.enggeo.2017.09.008.

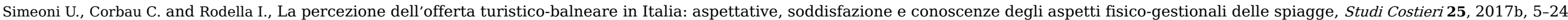

http://www.gnrac.unifi.it/rivista/Numero25/Articolo1.pdf.

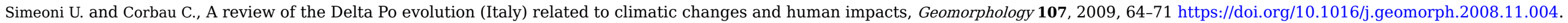

Simm J.D., Brampton A.H., Beech N.W. and Brooke J.S., A manual for beach management, 1996, Construction Industry Research \& Information Association (CIRIA). 
Stern P.C., Dietz T. and Kalof L., Value Orientations, Gender, and Environmental Concern, Environ. Behav. 25, 1993, 322-348, https://doi.org/10.1177/0013916593255002.

Tudor D.T. and Williams A.T., A rationale for beach selection by the public on the coast of Wales, UK, Area 38, 2006, 153-164 http://doi.org/10.1111/j.1475-4762.2006.00684.x.

Utizi K., Corbau C., Rodella I., Nannini S. and Simeoni U., A mixed solution for a highly protected coast (Punta Marina, Northern Adriatic Sea, Italy), Mar. Geol. 381, 2016, 114-127

http://doi.org/10.1016/j.margeo.2016.09.002.

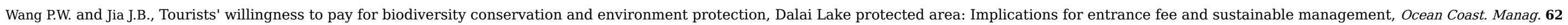
2012, 24-33, https://doi.org/10.1016/j. ocecoaman.2012.03.001.

Williams A.T. and Barugh A., Beach user perceptions at the eastern Yucatan peninsula, Mexico, In: J. Coast. Res. Proc. 13th Int. Coast. Symp., 2014, 426-430, https://doi.org/10.2112/SI70-072.1.

Williams A.T. and Davies P., Beach management guidelines: Dimensional analysis, In: Randazzo G., (Ed), Coastal environment management, 1999, EUCC; Italy.

Williams A.T. and Micallef A., Beach Management principles and practice. London, 2009.

Zhai G. and Suzuki T., Public willingness to pay for environmental management, risk reduction and economic development: Evidence from Tianjin, China, China Econ. Rev. 19, 2008, 551-566, https://doi.org/10.1016/j.chieco.2008.08.001.

\section{Highlights}

- Italian value of WTP for beach preservation is 14.84€.

- Italian beach-goers show low knowledge of beach issues and management.

- Logit model for evaluating the probability of a positive WTP are constructed.

- Beach urbanization level and beach typologies are significant predictors of tourists' WTP.

- WTP decreases from natural to semi-urban and finally to urban beaches.

\section{Queries and Answers}

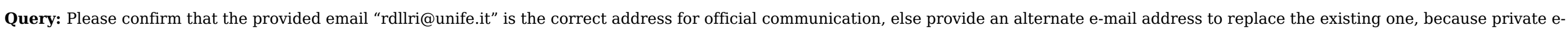
mail addresses should not be used in articles as the address for communication.

Answer: rdllri@unife.it is the correct email address

Query: Reference "James, 2000" is cited in the text but not provided in the reference list. Please provide it in the reference list or delete these citations from the text.

Answer: I deleted James, 2000 citation from the text

Query: Please provide a definition for the significance of bold in the Tables 6-13.

Answer: LL value: Log-Likelihood value

LL' value: Log-Likelihood value for the restricted hypothesis (related to the alternative model, without the constant term)

$\mathrm{X}^{2}$ : chi-square

$\mathrm{X}^{2}{ }^{(0.95)}$ : significative chi-square at 0.05 


\section{D.F.: degree of freedom}

S.E.: standard error $\mathrm{z}$ : z-statistics

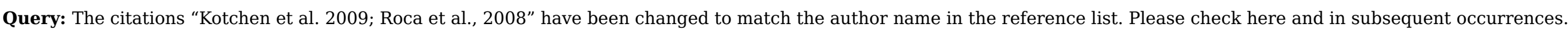

Answer: I checked the references approving the changes from: Kontogianni et al., 2009 to Kotchen et al., 2009 and from Roca et al., 2008 to Roca and Villares, 2008

Query: Please update Ref. Rodella et al., 2019.

Answer: This reference corresponds to data in brief paper (related to this manuscript). The paper is in rewiever process to now, therefore I currently do not update the reference

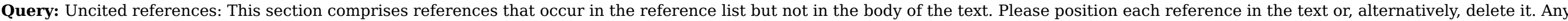
reference not dealt with will be retained in this section. Thank you.

Answer: I deleted the references Ariza et al., 2012 and Billè, 2007. On the contrary I added the citation Simeoni et al, 2017b in the text

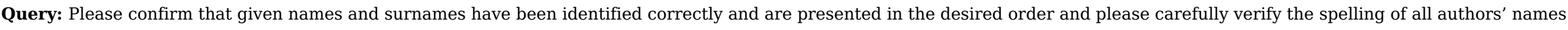

Answer: Yes

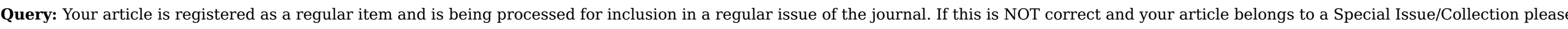
contact s.vadivelan@elsevier.com immediately prior to returning your corrections.

Answer: Yes 